aan het oordeel dat sprake is van een 'bij de belastingwet voorziene aangifte' in de zin van artikel 69 lid 2 AWR. ${ }^{37}$ Een als aangifte ingediende gegevensdrager kan uitsluitend worden aangemerkt als een 'bij de belastingwet voorziene aangifte' indien die aangifte is gedaan door degene op wiens belasting- of betalingsplicht die aangifte betrekking heeft, of door degene die uit hoofde van artikel 42 tot en met 44 AWR als vertegenwoordiger van de belasting- of betalingsplichtige kan optreden. Het middel ging uit van de opvatting dat ook buiten deze gevallen sprake kan zijn van het als pleger strafrechtelijk aansprakelijk zijn voor het onjuist of onvolledig doen van een bij de belastingwet voorziene aangifte als bedoeld in artikel 69 lid 2 AWR. Deze opvatting is dus onjuist. De Hoge Raad merkt voorts nog op dat artikel 47 tot en met $51 \mathrm{Sr}$ diverse mogelijkheden bieden om degene die anders dan als pleger betrokken is bij het onjuist of onvolledig doen van een bij de belastingwet voorziene aangifte, onder specifieke voorwaarden strafrechtelijk aansprakelijk te stellen voor die betrokkenheid. Onder omstandigheden kan een dergelijke gedraging ook opleveren het in artikel 225 lid 2 Sr strafbaar gestelde ('valsheid in geschrift'), welke delictsomschrijving tot eenieder is gericht.

\section{NTS 2020/47}

HR 21 januari 2020, 18/01333, ECLI:NL:HR: 2020:44

Opzettelijk dreigend teksten en foto's per e-mail te sturen naar A. Bedreiging a.b.i. art. 285.1 Sr?

\section{Aantekening redactie}

Volgens vaste rechtspraak is voor een veroordeling ter zake van bedreiging met enig misdrijf tegen het leven gericht onder meer vereist dat de bedreigde daadwerkelijk op de hoogte is geraakt van de bedreiging en de bedreiging van dien aard is en onder zodanige omstandigheden is geschied dat bij de betrokkene in redelijkheid de vrees kon ontstaan dat deze het leven zou kunnen verliezen ${ }^{38}$ en dat het opzet van de verdachte daarop was gericht. ${ }^{39}$ In deze zaak is de verdachte door het hof wegens (o.m.) 'bedreiging met enig misdrijf waardoor gevaar voor de algemene veiligheid van

37. Vgl. HR 5 juli 2011, ECLI:NL:HR:2011:BP3746 en HR 12 juli 2011, ECLI:NL:HR:2011:BQ3673.

38. Vgl. HR 7 juni 2005, ECLI:NL:HR:2005:AT3659.

39. VgI. HR 17 januari 1984, ECLI:NL:HR:1984:AC8252 personen of goederen ontstaat en met enig misdrijf tegen het leven gericht en met brandstichting' veroordeeld tot drie maanden gevangenisstraf, voorwaardelijk met een proeftijd van twee jaar, en tot een taakstraf voor de duur van 150 uur, subsidiair 75 dagen hechtenis. Het hof had bewezen verklaard dat de verdachte:

'op 3 februari 2015 te Amsterdam iedere politieagent die bij verdachte komt heeft bedreigd met:

- enig misdrijf waardoor gevaar voor de algemene veiligheid van personen en goederen ontstaat, en

- enig misdrijf tegen het leven gericht, en

- brandstichting,

immers heeft verdachte opzettelijk dreigend teksten en foto's per e-mailbericht naar [getuige] verzonden, te weten:

"Maar jullie kunnen mij niet uitlokken want ik zit in mijn bunker met 15 liter benzine en twee butaan gasflessen van 50 liter per stuk. Iedere huurmoordenaar en politieagent zal worden opgeblazen die hier komt.",

"[getuige], Thet wanna fuck with me? They fucking with the best. I take them all to fucking hell. Who? Me! That's who. Ik zal het complete gebouw opblazen wanneer ik maar één verdacht persoon of politieagent zie. Ik heb een gijzelaar en ze kunnen die jongen terugkrijgen wanneer ik een miljoen euro krijg en de liquidatieopdracht is ingetrokken. [betrokkene 1] heeft mij een Uzi gebracht en [betrokkene 2] twee handgranaten. Jij gaat de politie geen informatie geven dat ik bezig ben met mijzelf verdedigen en met een 'schoonmaak' en [betrokkene 3] kan dat beter ook niet doen. Ik ga iedereen in dit conflict vermoorden en daarna ga ik mijzelf en het gebouw opblazen.",

"Politie bellen is zinloos. Ik heb mij al verplaatst maar het gebouw is één boobytrap. Wanneer jij de politie informeert heb jij een explosie veroorzaakt.",

een foto met daarop afgebeeld een bed met daarop liggend een paspop afgedekt met een jas, en

twee foto's met daarop afgebeeld twee gasflessen aan elkaar verbonden door een elektriciteitssnoer met daaraan gekoppeld een mobiele telefoon, geplaatst voor een voordeur,

terwijl deze bedreiging schriftelijk en onder bepaalde voorwaarden is geschied.'

Het middel klaagde over de bewezen verklaarde bedreiging. Aangevoerd werd dat:

- het vreesobject 'iedere politieagent die bij verdachte komt' niet voldoende bepaald is;

- uit de bewijsvoering niet volgt dat de bewezen verklaarde bewoordingen bij 'iedere agent die bij verdachte komt' de redelijke vrees hebben kunnen doen ontstaan voor het in het vooruitzicht gestelde gevolg; 
- en uit de bewijsvoering niet volgt dat 'iedere politieagent die bij verdachte komt' schriftelijk en onder voorwaarden is bedreigd.

Waren deze 'Tony Montana-achtige' uitlatingen geschikt om bij 'iedere politieagent' redelijke vrees te doen ontstaan? Weinig specifiek gerichte dreigingen vereisen concrete aanknopingspunten in de omstandigheden van de zaak om redelijke vrees bij iemand te kunnen wekken. Het hof heeft vastgesteld dat blijkens de inhoud van de door de verdachte aan [getuige] gestuurde berichten en foto's sprake was van 'een voldoende concrete dreiging met een explosie gericht aan de agenten die zich naar de woning van de verdachte zouden begeven', dat [getuige] de politie daarvan op de hoogte heeft gesteld waarbij 'de politie de e-mails en de foto's van de verdachte zeer serieus heeft genomen' en de politie een observatieteam heeft ingeschakeld. Het hof heeft voorts geoordeeld dat de verdachte, gelet op de zeer dreigende inhoud van de berichten en foto's, bewust de minst genomen aanmerkelijke kans heeft aanvaard dat [getuige] met die berichten en foto's naar de politie zou gaan. Gelet hierop geeft het oordeel van het hof dat de verdachte 'iedere politieagent die bij de verdachte komt' heeft bedreigd op de wijze als bewezen verklaard, volgens de Hoge Raad niet blijk van een onjuiste opvatting omtrent het begrip 'bedreiging' als bedoeld in artikel $285 \mathrm{Sr}$ en is het niet onbegrijpelijk. Dat de verdachte zijn berichten, met foto's, niet rechtstreeks naar de politie heeft verzonden en dat tevoren niet vaststaat welke bepaalde politieagenten naar de woning zouden komen, maakt dat niet anders.

\section{NTS 2020/48}

\section{HR 21 januari 2020, 18/05326, ECLI:NL:HR:} 2020:78

\begin{abstract}
Gevaar op de meg kunnen veroorzaken en / of verkeer op de meg kunnen hinderen door met hoge snelheid op een crossmotor op een bospad te rijden, termijl dat bospad gesloten is voor motorrijtuigen, art. 5 WVW 1994 en zonder daartoe gerechtigd te zijn, zich met een crossmotor bevinden op een bosmeg, zijnde grond toebehorende aan een ander, van melke grond de toegang op een voor verdachte blijkbare wijze door de rechthebbende is verboden.
\end{abstract}

\section{Aantekening redactie}

De verdachte in deze zaak heeft vanaf 9:00 uur in de ochtend met een crossmotor gereden op een bospad dat kan worden aangemerkt als een weg in de zin van de Wegenverkeerswet 1994. Openbaar verkeer dat op deze weg is toegestaan, is beperkt tot wandelaars en fietsers. De verdachte reed met twee andere motorrijders op een tweeënhalve meter breed pad dat langs beide zijden dichtbegroeid was, waardoor het zicht onderweg onoverzichtelijk was, als in een tunnel. Dit zicht was door de laagstaande zon bovendien nog slechter en de verdachte reed daar met (te) hoge snelheid (ongeveer $60-80 \mathrm{~km} / \mathrm{u}$ ). De verdachte heeft zelf verklaard dat het bospad werd gebruikt door wandelaars, fietsers en ruiters, waaruit blijkt dat op dat bospad potentieel verkeer aanwezig was. Hiervoor is de verdachte door het hof veroordeeld tot een geldboete van $€ 1.000$ wegens 1 . 'overtreding van artikel 5 van de Wegenverkeerswet 1994' (een overtreding) veroordeeld tot een geldboete van $€ 1.000$, bij gebreke van betaling en verhaal te vervangen door twintig dagen hechtenis, en tot een geldboete van $€ 90$ bij gebreke van betaling en verhaal te vervangen door één dag hechtenis wegens 2. 'zonder daartoe gerechtigd te zijn, zich op eens anders grond waarvan de toegang op een voor hem blijkbare wijze door de rechthebbende is verboden, bevinden' (art. $461 \mathrm{Sr}$, een overtreding).

Het middel klaagde dat ten aanzien van feit 1 uit de gebezigde bewijsmiddelen niet blijkt dat op het in de bewezenverklaring bedoelde bospad regelmatig ongelukken zijn veroorzaakt door motorcrossers. Met betrekking tot feit 2 klaagde het middel dat uit de gebezigde bewijsmiddelen niet blijkt dat het bospad ten tijde van de bewezen verklaarde feiten gebruikt werd door wandelaars, fietsers of ruiters, waardoor uit de gebezigde bewijsmiddelen niet kan volgen dat een wandelaar, fietser of een ruiter door het rijden van de verdachte is en/of kon worden gehinderd, noch dat voor hen een gevaarlijke situatie is ontstaan. Artikel 5 WVW 1994 beoogt het belang van de verkeersveiligheid (middels het bestanddeel 'gevaar') respectievelijk de vlotheid van de doorstroming van het verkeer (middels het bestanddeel 'hinder') te beschermen. Het gevaar is gelegen in een reële of aanzienlijk verhoogde kans op schade van goed of lijf. Dat houdt niet in dat overig verkeer ter plaatse moet zijn, maar wel dat ter plaatse regelmatig ander verkeer aanwezig placht te zijn. Het verkeer moet met andere woorden 'werkelijk dan wel potentieel' aanwezig zijn. Gelet hierop is de opvatting die aan het middel ten grondslag lag, inhoudende dat, wil er sprake zijn van een gevaarlijke situatie als bedoeld in artikel $5 \mathrm{WVW}$ 1994, uit de bewijsvoering moet blijken dat dat gevaar of de hinder zich in het verleden regelmatig heeft verwezenlijkt, dan wel dat daaruit moet blijken dat op het bewezen verklaarde tijdstip daadwerkelijk personen aanwezig waren ten aanzien van wie dat gevaar en/of de hinder zich concreet moet hebben voorgedaan, volgens de Hoge Raad onjuist:

'Het Hof heeft, kort gezegd, geoordeeld dat de verdachte als bestuurder van een crossmotor met hoge snelheid heeft gereden op een weg, te weten een bospad waar het openbaar verkeer was beperkt tot wan- 